\title{
REVIEW S.
}

Art. XVII.-A Treatise on Military Surgery and Hygiene. By Frank IIastings Hamrlton, M. D., late Lieutenant-Colonel, Medical Inspector U. S. A. ; Professor of Military Surgery and Hygiene, and of Fractures and Dislocations in Bellerne Medical College; Surgeon to Bellevue Hospital ; Prof. of Military Surgery, \&c., in Long Island College Hospital ; Author of Trcatise on Fractures and Dislocations and of a Practical Treatise on Military Surgery. Illustrated with 127 engravings. 880. New York: Bailličre Brothers, 1865. pp. 648.

Turs volume contains twenty-six chapters. Following the introduction: are seven which treat respectively of the examination of troops, their gcneral liygienc, their accommodation in tents, barracks, lıuts, \&c, of hospitals, preparations for the field, the hyrrieuie management of troops upon the inarch, aud the con reyance of sick and wounded soldiers; the remaining ehapters are devoted to the consideration of the injuries received in warfare, and of those diseases to which soldiers are more particularly subject, with a fulal one on the employment of anæsthetics in major amputations and in other severe surgical operations after gunshot injuries.

The introduction is mainly devoted to the question of the military position of medical officcrs, the rank, and the authority they should enjoy. This question is one more delicate to treat than difficult to decide. It cannot be denied that the medical officers are entitled to the gradations of rank precisely as other officers are, aind that they have been unjustly treated by Congress in its legislation on the subjeet. T'hey slould be on the same footing with the other staff officers. Common sense would sccm to show that the medical directors of armies, corps, and divisions slıould have the same rank as the chief quartermaster, chief commissary of subsistence, chief engineer, chief of ordnance, \&c., of the same bodies. Medical officers should have the same authority in their departments that other staff officers have in theirs, no more and no less, and in all respects should be subject to the commanding officers, precisely as are other officer's. In the case of a regiment, which is always theoretically commanded by a coloncl, or of a smaller body of men, or a detached garrison, the medical officer should be subject to the orders of the commanding officer, no matter what his rank may be. Any other prineiple than that which recognizes that the officer lighest in rank in the line of the army shall command is crroneous, and will lead to disaster. No quartermaster, commissary of subsistence, entgineer, or other staff officer can command troops except by virtuc of a regimental commission, if he has one, and the surgeons should obey the same rule.

'The line officers, in an army officered by intelligent meu, who have been bronght $\mathrm{a}_{1}$, to their profession, or who have learned it by expericnce in the field, are well acquainted with the varions subjects of the diet and dress of soldiers, details of camps, receipts for food, teuts, soldiers' houses, equi\})ments, \&c. The medical officer who interferes in such matters will meet No. XCIX.-JunY 1865. 
with opposition, and properly so. In fact, the relations between the medical and line officers wonld in a well organized army make such interference almost impossible, and shonld it occur, it wonld show that one has gone beyond or the other has fallen behind his duty.

An instance, showing that officers who have thoroughly learned their professions can take care of thcir men, is given at page 93 , in the chapter on the general hygiene of troops, where Dr. Hamilton cites the cases of the 7 th Massachnsetts Regiment, Colonel Russcl, and the 2d Rlode Island, Coloncl F. Wheaton, Col. Russel, we know, entered the army from West Point in 1845, and Col. Wheaton entcred from civil life in 1855. Ir. H. says:-

"In our opinion the effcctiveness. value, and bravery of these two regiments were no less duc to the splendid talents of their respective colonels than to the perfect system of camp police maintained from day to day by surgeons Holman and Carr:"

Now the earnp police of a regiment is the charge of the officer of the day, a line officer. Is it not quite likely that these two efficient coloncls required not ouly the officer of the day, but also Surgeons Holman and Carr, to do their duty, and that, thercfore, the camp police maintained from day to day was perfect?

In thic seven cliapters of this work following the introductory one, the titles of which have been given abore, we do not find much to comment upon. They contain a great deal of uscful advice upon the various topics to which they are devoted. At page 76 , threc meals a day are said to be necessary for a soldier. Soldiers who are on a march soon get used to two meals a day. Old soldiers ncrer take more than two. The division of the men into squads of three or five for cooking the food, as reeommended by Dr. H., is not, we conceive, a good one. Where camp liettles can be carried the cooking should be by companies. The mell can then malse sonp, and soup has been unirersally acknowledged to be the best constant diet for the soldier. When the cooking is done in small messes, as here reeommended, solip canuot be made.

The remaining eighteen chapters, are, as already stated, devoted to military surgery.

Three years since, we laid before the readers of this journal, an aecount collected from the works of Scrive, Longmore, Guthrie, and Macleod, of the surgical expcrience of the Crimean Campaign, and on the same occasion took a brief glance at the then condition of the surgery of war. Since then a large hospital expcrience during the civil war in this country, and the valnable observations and memoirs contributed by others, have led us to modify or change our views in regard to many points conuected with military surgery. We propose, on the present occasion, briefly to state some of these changes, and also to indicate some points which appear to us to demand more attention than they have yet receircd. Whilc doing this, we shall refer to what is tanght and also to what is omitted in the volume before us.

According to our observation, the common opinion as to the action of conical balls is not correct. It is not their point that always first strikes, for they have been found imbedded in the cpiphysis of a bone by the base. They do not go straight forward, withont deviating in their course from the resistance of tissues, as we have witnessed in imumerable iustances. In one the ball entered alongside of the nose below the eye, and after divid- 
ing the portio dura on the same sidc, lodged in the hollow of the back of the neek, whence we removed it. We have taken several balls from the walls of the chest, when the wound of entrance was on the opposite side, and there was no reason to suppose that the cavity of the chest had been traversed. We recall an instance where a ball was remoxed from the anterior wall of the abdomen, the contents of which showed no symptom of lesion, that had entered one of the buttocks and had broken off a small sharp piece from the ilinm of the same side near the superior spinous process. That the splitting of a conical ball cannot occur, and that it nerer tonches a bone more gently than to occasion its utter destruction, as Macleod puts it, we have by no means fonnd to be the case. We have again and again removed a ball in several pieces from a limb when the bone had becu struck and not broken. In oue instance we removed a forcign body from above the elbow-joint, on the internal edge of the hnmerus, on account of the pain complained of in the terminal branches of the ulnar nerve, the skin had entirely healed over, and there was no trouble whatever at the seat of injury; it was a ball ent by the sharp edge of the bone almost exactly into two, still united by a very thin piece of lead, lying against the humerns, which was not broken. We recollect removing a conical ball from the external condyle of the right femur, where it was imbedded in the bony tissne, without having splintered the bone. In another case, which we remenber pointing out to Inspector-General Muir, of the British army, who told us the man would die unless the limb were remored, in which he was mistaken, there was a hole through the lower end of the tibia from before backward, and no splintering of the bone had taken place, at least none in the direction of the ankle-joint. ${ }^{1}$ Lastly, as regards the extraction of conical balls, we have not found it to be more difficult than to remove a spherical one; indeed we have fonnd the contrary to be the case, as the latter are decidedly more difficult to seize hold of.

In the local trentment of gnnshot wounds, water dressings at the temperature agreeable to the patient are very generally conceded to be the best. The advice gireu by Dr. Hamilton (pp. 205 et seq.) on this point is good, as is also that in regard to the application at the proper time, of the roller bandage, the advantage of which, when well applied, cannot be overestimated. The abuse of the probe and the rough handling of the parts have been so well commented upon by Dr. Hamilton that we will transeribe what he says on this subject:-

"It onght to be well understood that granulations, whether forming in the track of a sinus or at the surface, must be treated with great tenderness; any lesion of their delicate structure, whether occasioned by a probe, by the dressings, or by pressure with the laands, and which is sufficient to cause them to blecd, is hurtful; thc lesion thus produced must be again repaired, additional inflammation and suppuration result, as a direct conserinence of the injury, and in a greater degree the suppuration is increased and rendered more acrid, indirectly by the decomposition of the blood whicl remains. The simplc act of introducing a probc into an irritable sinus very often devclops an irritative fever which continnes several days, and not unfrequently determines an erysipelatous inflammation which resulis in death. . . . Violent pressure with the hand up and down a limb, in order that the last drop of pus may be forced out, is more liurtful to the patient than probing, just in proportion as it is more painful. . . . . Caution inust be exercised cven in the removal of detached fragments of bone, when patients are exhausted by long suppuration."

I The injury in this case may not hare proceeded from a conical ball, but this is not probable. 
Contrary to what is very generally said by modern anthors in regard to the use of the trepan, while we believe we have eause to regret not having lad reeourse to it in some gunshot wounds of the head, we always were pleased with the result when we did so. As the subjeet is one of great diffieulty and of particular importanee, and moreover, as very little has been written on the subjeet duriug the war, we will briefly relate some of these eases, that the reader may draw lis own inferenee as to what they teach. There is no more diffeult point to deeide in practiee than the extent to whieh surgical interferenee shall go in the treatment of similar eases.

Case I. Lewis Duluall, private Co. K, 12th Maine, at. 21, was wounded on the 19th Oetober, 1864, and adnitted on the 23d to the Satterlee U. S. General Hospital. ${ }^{1}$ We saw this patient for the first time on the loth November. Until then he had been liept quiet, and upon low diet with water dressings to the sealp. He was eomatose, and the right upper extremity was paralyzed. There was a guushot wound about the midule of the left frontal bone, whieh was fraetured, the fraeture being about four inehes in length, and running direetly baekwards; the edges of bone were depressed, and there were several small pieees lying loose between then. The loose pieees of bone were removed, and the depressed portions elevated. The clura mater was found intaet. The man improved at once, so that five days afterwards lie was walking about the ward entirely free from any symptom of nervous disorder. His reeovery was perfeet,

CASE II. Riverius H. Trask, prizate Co. H, 114th N, Y. Tols, wt. 23, was admitted from Sandy Hook Hospital, Maryland, September 25tll, 1864, with a gunsh ot wound of the head reecired in the battle of Winchester, Virginia, September 19th. He said he had been slightly stunned by the blow; his mind was confused, and his articulation diffeult. The ball had passed antero-posteriorly over the left frontal protuberanee, produeing a seemingly slight tlesh wound about half an ineh wide and one inch loug. The man's general lienth was good, and the wound looked bealthy. IIe eomplained, howerer, of a dull heary pain just orer the left brow, and the pupils of the eses appeared to be rather dilaterl. Ordered to keep quiet, on low diet, with water dressings to the wound. September 26 th, pain more severe, and pupils more dilated. On the 27 th, the man had a severe epileptie fit, that lasted about forty-five minutes; and remained afterwards in a state of semi-eonseiousness, with a pulse full, regular, and very slow; pupils much dilated; and for two hours after the convulsion the respiration was stertorons.

On the following day an anæsthetie was administered, ${ }^{\text {a }}$ and a free erueial ineision of the sealp over the wound, then almost eicatrized, was made. A well-marked depressed fraeture of the bone was found. By the elevator, ahout one and a half square inehes of the outer table were removed. The inner table was then found to be fissured, and uearly the same amount of it was takell away. The dura niater was found greatly eongested. On reeovering from the effeets of the anmsthetie, the inan seemed to breathe more freely, and said that he had less pain than before the operation. Two teaspoonfuls of the solution of morphia were given, aud repeated in two lours, so that he remained perfeetly quiet; no food whaterer was

\footnotetext{
I To avoid repetition, we will state that all the cases here related or referred to were observed in this hospital.

2 For this purpose a mixture of sulphuric ether (three parts) and of chloroform (one part) was always employed.
} 
allowed for the first day, and for twelve days he was not permitted to have any other nourishment than the essence of beef. On account of all attack of elysipelas of the head and face, that began on the fourth day of the operation and lasted for about one week, the tincture of the chloride of iron was administered frcely for several days. On the 11 th October, some light food was allowed in addition to the essence of beef; and on the 20th, he was placed ou full diet. By the middle of Novenber, the wound-the edges of which we made no attempt to bring together-had closed, and the man was perfectly well.

Case III. Herman L. Page, corporal Co. K, 1st Mass. Artillery, xt. 20 years. Was wonnded at Petersburg, June 17, 1864, by a ball (minié, in all probability) which struck the head at a tangent, about the posterior internal portion of the left parietal bone. At the bottom of the wonnd in the scalp, which was about two inches in length, the bone was denuded of periosteum, and several small bits of lead were tightly fixed in its small irregularities. The wound was healthy, and the man appeared perfectly well in all respects, when he was found speechless and paralyzed in his bed in the morning of the 3d July. By means of the trepan, on the same day, the outer table of the part of the cranium dennded of periostenm was removed; no fissure was found in it, and the diploe seemed healtly. Some improvement in the motions of the tongue was supposed to be witnessed, and further proceedings were postponed. Purgation by croton oil was practised. The next day, the 4 th, the man being in the same condition, the trepan was applied to the inner table, a fissure, oval shaped, one inch in the long by half an inch in the short diameter, was then discovered. This fssure wonld not admit of the introduction of a finely pointed quill tooth-pick, aud the bone was not loosened or depressed. This bony portion was removed, and beneath it the dura mater was found highly congested. A purulent collection was feared underneath this place; but it was judged most prudent not to incise the cerebral membranes. The man died at $4 \mathrm{~A}$. M. of the 7 th July.

A.t the autopsy, a large abscess was found, filled witl fetid pus, cxtending from the top of the left cerebral hemisphere to its base.

CASE IV. William H. Burger, sergeant in Co. K, 47th Pa. Vols., was admitted Oct. 25, 1864, from Regimental Hospital, with a transverse scalp wound one and a half inch in length, on the left side of the head, over the frontal bone, near the coronal sutmre and the junction of the left frontal and parictal bones. The wound, said by the man to be from a piece of shell, was received at Cedar Creek, Virginia, October 19th. The bone was denuded of periosteum the whole length of the wound; no fracture was discovered. The man complained very little; the wound was healthy; there was diarrhca for several days after admission. The right side became partially paralyzed; the pupils became dilated; on the 27 th the man had a slight chill ; his feces were discharged involuntarily; the paralysis increased; on the 28 th there was a severe chill; he died on the 5th November.

At the post-mortem examination, on removing the scalp the portion of bone underneath the wound prescnted a dull white appearance. The external table was fissured on the left side of the longitudinal sinus; the fissure running across the sinus about a quarter inch, and separating the sagittal suture in its passage. On removing the calvarium a fissure with a depression of the internal table was discovered just to the left of the longitudinal sinus. The ressels of the membranes of the brain were much congested, and some pus was found on the surfuce of the dura mater. The 
dura mater itself presented a dark, almost gangrenous, appearanee. Under the dura mater, immediately beneath the wound, was found a large abscess in rolving nearly oue-half of the left cerebral liemisphere, extending nearly to the left lateral ventricle. The remaining half of the right lateral rentriele was much softened by the infiltration of serum. In the posterior base of the right lateral ventricle was found a small quantity of pus.

Our experience, then, iu injuries of the hend, and this is true of civil as well as military practice, would lead us to adopt a differcnt conlse from what we nsually find advised by modern surgical writers.

To turn to the book befure us, Dr. Mamiltou believes that the patient's chances of recovery are better if left alone than if we proeeed to operate (p. 237), and he says that "in trephining, sufficient additionil injury is often caused to turn the balance in the scale against recovery" (p.238). Several original cases of gunshot injuries to the head are given "to illustrate how much nature can accomplish nuder the nost unfavourable circumstances, without aid from the surgcon." III one of injury (at page 242) at the back part of the oceipital bone, the man was walking about and feeling well on the 24th dily when Dr. II. saw him. In another (same page) where the skull was fractured aud depressed-we are not told in what place-the man was improving rapidly, after having had delirium and convulsions, at the expiration of four weeks. That such cases signify nothing, however, from the short time they were under observation, may be learncd from others afterwards related by Dr. H. liimself. There are two of penetrating gnushot wounds of the hend at page 244 ; in one no cerebral symptoms manifested themselves until about seven weels after the receipt of the injury, and at the end of eight the man died from the formation of abscess in the anterior lobes of the brain. In the other during the first eight weeks no cerebral symptoms were present, and at the expiration of ten the man was dead.

Before leaving this subject of gunshot iujuries of the head, we will relate a case of at least temporar'y recovery, where the ball entered the cavity of the cranium, as an interesting surgical curiosity, and also with the liope of beiug enabled thereby to hear its ercntual termination.

George Guptill, private, Co. K, 29th Mainc, xt. 24. Aduitted Oct. 23, 1864. He was wounded on the 19th, at Cedar Creek, Virginia. The ball passed through the upper lid of the left eye, which was destroyed, and penetrated the orbital plate of the frontal bone. Several pieces of the orbital plate that were loose were removed. The nau was kept on his back ou a rigid diet, in a dark room, with cold-water dressings over the wound. No attempt was mude to find the ball further than by the introduction of the finger into the wound. The pulse was decidedly cerebral, slow and irregular.

The man had an attack of erysipelas dnring the first ten days after the receipt of the injury. For several days about the beginning of November he complained greatly of pain and twitching of the muscles in the feet. Occasionally he had headache. On the 20th November he was allowed to sit up for the first time. On the Tth January, the wound, which had been kept open as long as auy discharge issued, had closed, and he was discharged apparently well a few days afterwards.

Of what we have seen of injnries to the spinal column and its contents we have nothing to say, from our own observation, but what would be altogether superfluous after the excellent article of Dr. Lidell, published in the number of this journal for October 1864. In the work before us in 
the chapter on gunshot wonuds of the abdomen, there is about one page occupied with injuries of the vertebre, and no more is said on the subject in the whole work. The remaining portions of the nervous system are passed over without any mention whatever, although the late Surgeon General considered them of sufficieut importance to assign a special hospital for their study.

'The injuries of the bones, cansed by balls, are those of all others whose final resnlt has most grievonsly disappoiuted all our ealcnlations. The effect of a slight touch upon one of the bones of the eranium from a grlaucing shot is seen in some cases related above. We have again and agaiu seeu a stout fellow sink wheu one of the long bones had been tonelied so slightly as merely to carry off a small pieee of periosteur. When this happened in the femnr death always followed. As a paper upon gunshot coutusion of bone has been prouised, as a eontribution to this journal, by one more competent than we are to treat of it, we shall satisfy ourselves with this short referenee to the subject. Should such cases again fall under our eare, we shall proeeed at onee to trepan the bone at the seat of injury. Of such injurjes no mention is made by Dr. Hamilton; and he is equally sileut about osteo-myelitis, which is even more astouishiug, for it is a subjeet to which particular attention has beeu ealled, and upon which a grent deal has been written in late years. The paper receutly published in this journal by Dr. Allen may here be eited as one of special value ou this most distressing coruplication of gunshot wounds. When the stump of an amputated limb snfiers from this affection, we have repeatedly verified the eor'rectness of the advice reeeutly given by $\mathrm{Mr}$. Long'more, namely, that it is better to wait for the elimination of the portions of boue that are to die, than to amputate at the joint above. In one ease where the lel't femur, or what was left of it, was thus affeeted, nearly two years elapsed before the stump liad perfectly healed.

Iu cases of gunshot wounds where the bones are brokeu, eitler into the joint or not, whether of the upper or of the lower extremity, we have fajled to see, as we had hoped to do, that resection may be substituted for amputation, as exposing life to less dauger, or seenring a more useful limb. If amputation be not performed, we are satistied that the surgeon should simply reluove loose splinter's of bone, and also those but slightly adherent, and theu apply an apparatus to keep the parts as quiet and in as good position as possible. Resections, as a elass of operations, have failed in military surgery. There is a long chapter in the work before us entitled Fxsections, but it is only calculated to gire iuformation to the student of operative surgery. The same remark applies almost equally well to the chapter headed "Amputations." It contains, it is true, some cousiderations upon the eonditions of the limb in army practice demauding amputation, the point at which amputation is to be made, the mcthod, and the period of time at which it ought to be made; but those cousideratious contaiu nothing new, and they have been far better treated by other writers. Let any one, for example, compare those upon the eouditions of the limb that demand amputation, with the indications given by Stromeyer. Upon this subject, again, we arc able to refer to an admirable paper by Dr. Lidell, pnblished in the April number of this jourual. By no other writer has the proper time for performing ampntation been so satisfactorily discussed.

On the subject of gunshot wounds of arteries we arc, ouce again, so fortnnate as to have a paper of Dr. Lidell (see this jourual for Jauuary, 1864) to refer to. Upon one point only we eannot agree with him, and that is 
the expediency of abstaining from performing any operation upon a wounded artery for hemorrhage unless it bleed at the time. This is the course he prefers, for the renson given that it frequently happens, cren in apparently unpromising cases, that a hemorrhage stopped spontaveonsly or by simple means does not return (loc. cit., page 115). This is also, as we know, the advice given by Guthrie. Wc have too often been deceived, ourselves, in the hope of sceing the blceding stop, to have confidence in this. Besides, as Legonest says, hemorrhage kills not only by loss of blood but also by the anguish and dread it excites. It is a most pitiable sight to see men awaiting in fear an accident whose gravity thcy know instinctively. Dr. Lidell says that "to ligate the artery in such a case would be to inflict unnecessary torture upon the sufferer." In this we think him to be mistakeu. We have always seen the man under these circumstances most desirous of nndergoing the operation, and highly gratificd when it had been accomplished. As to the torture of the operation itself, the use of an anæsthetic pats this out of the question.

We here finish our brief and somewhat hasty remarks on some of the most prominent points in the surgery of war, in which the whole profession in this country has, for several years, been deeply interested. What we have scen and done ourselves, it should be stated, was in a hospital in this city, and not in the field, not at City Point, nor at Washington. In other words, it was for the most part only the remote waves of the distant storm that we saw, and from which we made our observations.

We have already, from several references to the book before us, by Dr. Hamilton, said enough to show that we have found it to be in several respects defective and incomplete. Some of those subjects, which are of the highest and most special importance to the army surgeon, are altogether omitted. In addition to some already mentioned may be cited nostalgia, sunstroke, congelatious, and even pyæmia.

As a general rule, original cases, for which we looked with some expectation, are, throughout the book, of snch a character, from incompleteness, as to be quite valueless. Some examples of this were given when speaking of wounds of the head, and there are others equally remarkable elsewhere. Of what value, for example, are such cases as these, taken from the chapter on Gunshot Wounds of the Thorax.

"Isaae Etchell, a private in the 72d Penna., was wounded at Antietam, on the 17th of Sept., 1862, by a round ball, which entered the left side of the elest in front, three inches above and to the left of the nipple, passing completely through. He expectorated blood inmediately and freely, but it soon eeased and never recurred. On the twenty-fourth day the wound had closed, and he wis sitting up, but he continued to suffer from pain and a sense of oppression over the whole of the left side. Having never seen him since, we are unable to state the final result."

"Moses Haseltine, a private in the 12th Mass., was wounded at $\Lambda$ ntietam by a ball whieh entered the thorax two inches outside of the left nipple, and passed entirely through the body. He expectorated blood within ten minutes, and continued to do so for nine or ten days. Air had eseaped through the wound in the back. Suppuration was frce on the twenty-third day; he had eonsiderable eough, and was looking thin and pale."

To be told that twenty or thirty days after being shot in the thorax a man snffered pain and had a sense of oppression, or had considerable congh, and was Iooking thin and pale, does not inform us even as to the then present condition of the parts in the thoracic eavity, which anscultation and percussion would have done. Still less does it throw any light 
npon their final termination, and this in these cases reqnires elıcidation. Although we have treated a large number, and had many under our carc for many months, we feel ourselves as yet quite in the dark as to the final results in gunsliot wounds of the thorax.

In concluding this review, it may not seem ont of placc to give expression to our feeling of decp regret that the able and highly intelligent surgeon, who had collected with indefatigable indnstry so many valuable materials for the surgical listory of our war, and who had made great progress towards the completion of the work, has not had the privilege afforded him of finishing his task. Had this been done, the profession could look with greater confidence for a full account of what medicine lias donc in its bloody fields and crowded hospitals, snre that, so far as we are concerned, it shonld lot be said of this drcadful war, caruit vate sacro.

W. F. A.

Art. XVIII.-Lectures on Epilepsy, Pain, Paralysis, and cerlain other Disorders of the Nertous System, delivered at the Royal College of Physicians in London. By Chartes Bland Radcliffe, M. D., Fellow of the Royal College of Physicians in London, Physician to the Westminster Hospital, \&c. London : John Churchill \& Sons, 1864.

A PIIYSICAL thcory of innervation and muscular action must, if established, be a grand adrance in physiology. If its application to pathology and therapentics be direct, and, most of all, if it tend to canse a revolution in practice, such a theory must have great importance. Has Dr. Radcliffc furnished us, in the work entitled as above, with this desideratum? Not without some sympathetic enthusiasm for the inquiry, excited by his own manifest though intelligent zeal, we have endeavoured to do justice to this question, by a careful study of the work. If our conclusion be not such as to satisfy either its autlior or our rcaders, it will not be from want of atten. tive consideration of the argument.

Twelve year's soonel, as Dr. Radeliffe states in his prefacc, he published an essay on the "Philosophy of Vital Motion ;" and afterwards other volumes, in which he endearoured to show that it was necessary to revise the current theory of muscular motion, and to consider muscular contraction as "a physical process in which the attractive force inherent in the physical constitution of the muscular molecules was the contractile agent;" and, in conseqnence, that a radical change was called for in the pathology and therapeutics of convulsion, tremor, and spasm. Since the last ${ }^{2}$ of these works was printed, he has found occasion to add further evidence in favour of his doctrinc, and to extend its application to the physiology of sensation, and the therapeutics of pain and paralysis.

In the essential idea upon which he starts in all of these investigations, others had anticipated him to some extent. Dr. West, of Alford, as mentioned in Dr. Radcliffe's appendix, main tained distinctly, in 1832, that "the nervous influence present in relaxed muscular fibre is the ouly influence which the nerres of volition possess over that tissue; that its office is to restrain or coutrol the tendency to contract which is inlerent in the muscle:

1 Epileptic and other Convulsive Affections of the Nervous System, and their Treatment Incorporating the Gulstonian Lectures for 1860 . 